\title{
Direct cost method applied to calculate milk production costs
}

\author{
Aplicação da metodologia de custeio direto para apuração dos custos de produção de leite \\ Aplicación de la metodología de costeo directo para calcular los costes de producción de leche
}

Received: 01/03/2022 | Reviewed: 01/09/2022 | Accept: 01/15/2022 | Published: 01/17/2022
José Leoncio Delmondes Pereira Freitas ORCID: https://orcid.org/0000-0001-8370-7367 Universidade Federal de Sergipe, Brazil E-mail: jleoncio@constarnet.com.br
Evandro Neves Muniz
ORCID: https://orcid.org/0000-0003-2806-229X EMBRAPA Tabuleiros Costeiros, Brazil E-mail: evandro.muniz@embrapa.br
Anselmo Domingos Ferreira Santos
ORCID: https://orcid.org/0000-0002-9041-4308 Universidade Federal de Sergipe, Brazil E-mail: anselmosantos@ufs.br
Sônia Magna Moura Delmondes Freitas ORCID: https://orcid.org/0000-0002-1495-7343 Universidade Federal de Sergipe, Brazil E-mail: sonia@constarnet.com.br
Luana Moura Delmondes Freitas ORCID: https://orcid.org/0000-0001-5100-0105 Universidade Federal de Sergipe, Brazil E-mail: delmondes.luana@gmail.com Valdir Ribeiro Júnior
ORCID: https://orcid.org/0000-0001-6090-1108 Universidade Federal de Sergipe, Brazil E-mail: valribjunior@academico.ufs.br
Leda Maria Delmontes Freitas Trindade ORCID: https://orcid.org/0000-0003-4300-4274 Universidade Tiradentes, Brazil E-mail: ledeltrin@gmail.com
Gladston Rafael de Arruda Santos ORCID: https://orcid.org/0000-0002-7554-9351 Universidade Federal de Sergipe, Brazil E-mail: gladston@academico.ufs.br Camilla Mendonça Silva
ORCID: https://orcid.org/0000-0001-5259-9316 Universidade Federal de Sergipe, Brazil E-mail: camilla2019@academico.ufs.br

\begin{abstract}
The objective was to apply direct costing (DC) methodology to calculate dairy farms costs located in the semiarid region of Sergipe, Brazil. Productive and financial data were used from 30 dairy farms, in which milk market is the farms primary activity. Costs were segregated as fixed and variable, as profitability index, contribution margin (CM) and net income (NI). Profit before interest, taxes, depreciation and amortization (EBITDA) was adopted as financial index. In rural farms analyzed, CM was negative equivalent to $\mathrm{R} \$-0.06$ per liter of milk, due to the high production cost setting the sold goods cost (COGS), exceeding the net income by 4.49 percentage points, equivalent to R $\$ 1.31$ per liter of milk, contributing to the result of $\mathrm{R} \$-0.20$ (twenty cents) per liter of milk, equivalent to $-16.8 \%$ of the raw milk price. The direct costing methodology has applicability to calculate costs in dairy farming, as it provides full data and information from the economic-financial point of view, well segregated.
\end{abstract}

Keywords: Costs; Contribution margin; Dairy farming; EBITDA.

\section{Resumo}

Objetivou-se aplicar o uso da metodologia do custeio direto (CD) para apuração dos custos de fazendas leiteiras localizadas no Semiárido Sergipano, Brasil. Os dados produtivos e financeiros utilizados foram provenientes de 30 propriedades rurais leiteiras, ao qual a comercialização do leite é a atividade primária dessas propriedades. Os custos foram segregados em fixos e variáveis, como índice de rentabilidade foram utilizados a margem de contribuição (MC) e lucro líquido (LL). Como índice financeiro adotou-se o lucro antes dos juros, impostos, depreciação e amortização - 
LAJIDA. Nas propriedades rurais analisadas a MC foi negativa, equivalente a R - 0,06 por litro de leite, devido ao elevado custo de produção que compõem o custo de produtos vendidos (CPV), que superou a receita líquida em 4,49 pontos percentuais, equivalente a $\mathrm{R} \$ 1,31$ por litro de leite, contribuindo para o resultado de $\mathrm{R} \$-0,20$ (vinte centavos) por litro de leite, equivalente a $-16,8 \%$ do preço bruto do leite. Conclui-se que a metodologia do custeio direto tem aplicabilidade para apurar os custos na pecuária de leite, por fornecer dados e informações mais completas sob o ponto de vista econômico-financeiro, bem segregados.

Palavras-chave: Custos; Margem de contribuição; Pecuária de leiteira; LAJIDA.

\section{Resumen}

El objetivo fue aplicar el uso de la metodología de costeo directo (CD) para calcular los costos de las granjas lecheras ubicadas en la región semiárida de Sergipano, Brazil. Los datos productivos y financieros utilizados provienen de 30 granjas lecheras, en las que la comercialización de la leche es la actividad principal de estas propiedades. Los costos se segregaron en fijos y variables, utilizando el índice de rentabilidad, el margen de contribución (MC) y lo ingreso neto (IN). Se adoptó como índice financiero la utilidad antes de intereses, impuestos, depreciación y amortización (EBITDA). En las propiedades rurales analizadas, el MC fue negativo, equivalente a R \$ - 0.06 por litro de leche, debido al alto costo de producción que compensa el costo de los productos vendidos (CPV), que superó el ingreso neto en 4.49 puntos porcentuales, equivalente a R \$ 1.31 por litro de leche, contribuyendo al resultado de -0.20 (veinte centavos) por litro de leche, equivalente al $-16.8 \%$ del precio de la leche cruda. Se concluye que la metodología de costeo directo tiene aplicabilidad para calcular los costos en la ganadería lechera, ya que brinda datos e información más completos desde el punto de vista económico-financiero, bien segregados.

Palabras clave: Costos; Margen de contribución; La ganadería lechera; EBITDA.

\section{Introduction}

Given the heterogeneous characteristics of dairy farms in Brazil, it is important and necessary to evaluate economic indicators that support cost management of this activity (Santos and Lopes 2014), in addition this information can reinforce possible public policies definitions in the country's dairy sector (Lopes et al., 2016).

Determining production costs is not a simple task involving a large volume of calculations (Sabbag \& Costa 2015). Traditionally, methodologies for measuring milk production costs are based on the total production and in total operating costs (Perez Jr. et al., 2012). However, these methods admit disbursements as costs incurred in a given period, failing to recognize investments in inventories and directly attribute to the result of the period values that have not yet been used in production, affecting the economic result of the production cycle (Sabadin \& Vizzotto 2014). In theory, from accounting point of view, costs varying with production must be recognized concomitantly with the respective revenues, keeping in stock the values equivalent to the finished and unsold products, such as the remaining milk stocked in tanks and disused or discarded animals, which remained on farm in the change of month, year or production cycle.

In this sense, direct costing method, widely used by the secondary and tertiary sectors, segregates costs into fixed and variable, considering the volume produced (Perez Jr. et al., 2012), which should be the only inventories composing the stocks, that when consumed, they become and remain as progress/finished stocked products until being sold, at which time they are written off from stock and transformed into sold products costs (SPC), thus preserving the competence principle above mentioned.

For Segala and Silva (2007), an important aspect using direct costing (DC) is the simultaneous revenues and costs recognition corresponding with the possibility of application in any cost determination system. In addition, DC for not using apportionments simplifies the calculation and, as fixed costs do not make part of the products costs, facilitates the operation results management, given that they do not depend on the volume produced (Souza et al., 2016). Also, according Junior (1999), it is highlighted that DC facilitate to know the contribution margin helping in the cost/volume/profit analysis, showing how much and which products contribute to cover fixed costs, promoting to define goals and obtain point of balance. Thus, given the context, the objective was to apply the use of the direct costing methodology to calculate the costs of dairy farms located in the semiarid region of Sergipano. 


\section{Methodology}

For the purpose of the current research, a case study analysis was applied as suggested by Ludke and Andre (2013), from the collection of numerical data from dairy production systems. The main criteria used to select rural properties were the producers' financial dependence on dairy activity, as well as its technological profile, with the use of mechanical milking. In addition, structured oral interviews (Marconi \& Lakatos 2011; Rosseto et al., 2020) were applied in loco, based on a questionnaire with 101 questions, divided into eleven categories as qualification, herd, production, personnel, nutrition, reproduction, health, movable goods, fuel, expenses fixed income, sales revenue and financial results (Sabbag \& Costa 2015).

The analyzed data were collected from 30 dairy production systems located in the semiarid region of Sergipano, where the primary activity is the marketing of milk. The information obtained corresponded to the period from April 2018 to March 2019, as a complete production cycle.

For financial data analysis, direct costing (DC) was adopted in which the costs were segregated into fixed and variable, with fixed costs being directly related to the period evaluated result, and with no direct relationship with production, such as: fees, depreciation, family labor, bank interest and stock (Table 1).

Fixed costs were obtained based on the average purchase prices of materials and/or products. Labor values were based on the average daily price of $\mathrm{R} \$ 50.00$. Furthermore, for electricity and water costs, the average monthly amounts charged by suppliers were considered.

Table 1. Cost elements that make up the stock of milk in progress, based on the direct costing method.

\begin{tabular}{ll}
\hline Elements & Classification \\
\hline Animal nutrition & Variable \\
Direct labor (DL) & Variable \\
Animals sold & Variable \\
Electricity & Variable \\
Milking material & Variable \\
Animal health & Variable \\
Animal breeding and improvement & Variable \\
Water & Variable \\
Fuel and lubricant & Variable \\
General maintenance & Variable \\
Indirect labor $(\mathrm{IL})$ & Fixed \\
Bank interest rate & Fixed \\
General costs $(*)$ & Fixed \\
Depreciation & Fixed \\
Family labor & Fixed \\
\hline
\end{tabular}

(*) Fees, internet and accounting. Source: Authors.

While variable costs, were called good sold costs (GSC), calculated based on materials consumption, direct labor, in the period under analysis (Figure 1). At the end of each month, based on the volume of milk produced, milk production cost was calculated by dividing the total variable costs by the volume of milk produced; thus, obtaining the unit variable cost of milk, regardless of disbursements. 
Figure 1. Flowchart of direct costing. (1) Electric power and water; (2) Food, medicine, milking material, artificial insemination; (3) Good sold cost (GSC); (4) Administration labor, maintenance, depreciation and financial expenses.

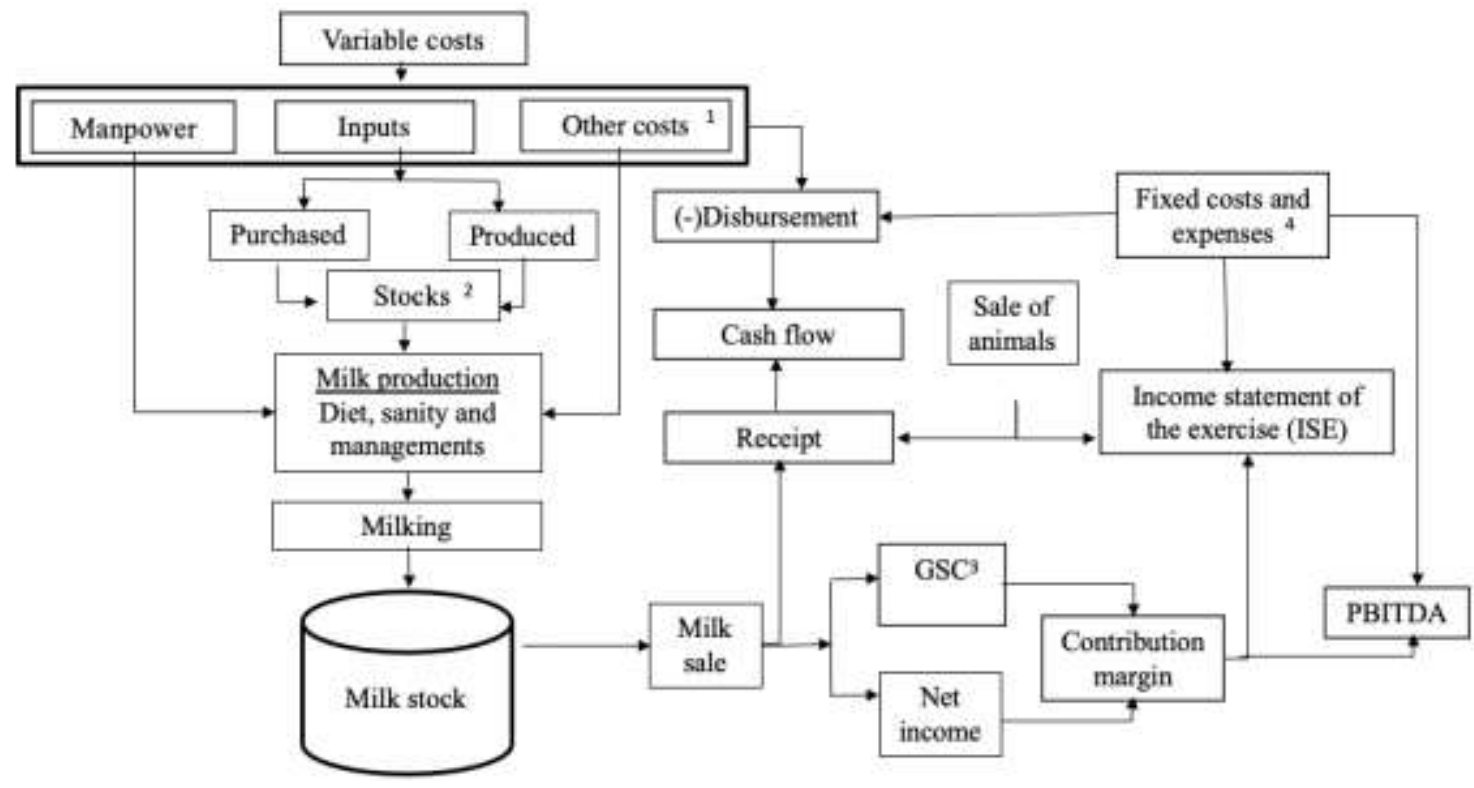

Source: Authors.

The unit cost of a liter of milk was used to obtain the GSC calculated by multiplying a milk unit cost by the volume of milk sold. In addition to GSC, as variable costs, costs with animals sold equivalent to their sales price were also considered.

Gross milk revenue was calculated based on monthly milk production, in liters, multiplied by the average gross unit price (Almeida, 2010). The amount retained by dairy products was equivalent to $1.5 \%$ of the gross price of milk as the Rural Worker Assistance Fund, in Portuguese Fundo de Assistência ao Trabalhador Rural (FUNRURAL), Federal Law 11/71 (Brazil, 1971), which when reduced from the gross revenue makes up the net income (NI). Revenues from cull animals sales were considered and obtained based on the annual quantity of animals sold divided by twelve months, then multiplied by the average price, in November/2019, of $\mathrm{R} \$ 153.70$ for about 32 pounds of meat (one arroba), assuming 50\% of carcass yield and average weight of $479.70 \mathrm{~kg}$ per animal, according to Emdagro (2013).

The values related to the depreciation of the assets were obtained in accordance with the tax legislation, Decree 9,580/18 (Brazil, 2018), considering as assets depreciation annual value the following percentages: vehicles $20 \%$, buildings $4 \%$, machinery and equipment $10 \%$ and herd $20 \%$ per year. The goods values were obtained according to their nature, being: a) movable goods: values informed by the producers themselves; b) livestock: values based on calculation artifice considering the equivalent animal cost to its sale price; and c) farm value: based on the cost of $\mathrm{m}^{2}$ at regions nearby for the buildings and land value per hectare. This method was used because the values and acquisition date of collected goods were not available.

Financial expenses with bank interest were computed according to each loan/financing contract, informed by the producer, related to monthly interest rates based on the amount paid annually, based on the interest rate established in contracts equivalent to $2.5 \%$ of the year. The amounts related to the remuneration of working capital were calculated based on the value of the assets at the rate of $6 \%$ per year. The value of remuneration on land was considered $1 \mathrm{~kg}$ of milk/ha/day (Lopes et al., 2004).

For the profitability indexes by DC method, were adopted the contribution margin (CM), net income minus GSC, and net income as financial index obtained from income before interest, taxes, depreciation and amortization (EBITDA) (Souza et al., 2019) and net income equivalent to subtracting the value of depreciation of machinery and improvements and bank interest from EBITDA (Costa et al., 2009). 
For the purposes of this study, it was considered sales amounts for milk and animals received during the production cycle. Likewise, the following were disregarded: a) possible balances, initial and final from materials and/or products stocks; b) sales amounts not received by producers at the beginning and at the end of the production cycle; c) payable amounts to suppliers, employees, banks, among other creditors at the beginning and end of the production cycle.

All data were submitted to Shapiro-Wilk residuals normality test and Levene test for variances homogeneity. Variables were considered as non-parametric for not showing normality and/or homoscedasticity, and were analyzed using the PROC NPAR1WAY. To develop statistical analyzes SAS statistical package (SAS Institute, v.9.3, Cary, North Carolina) was used.

\section{Results and Discussion}

Considering the detailed items that compose good sold costs (GSC) (Table 2), it is possible to observe that animal nutrition had the greatest monetary participation, accounting $\mathrm{R} \$ 18,292.00$ of the total costs, demonstrating that this item possibly has a great impact on the GSC. Similar scenario was evidenced by Silva et al. (2020), verifying that $66.64 \%$ of the total costs of a dairy cattle farm came from nutrition.

Table 2. Average values and average standard error (EPM) of the elements that make up the cost of goods sold (CPV/R \$) of the properties analyzed in the period from April/2018 to Mar/2019, in Brazilian currency (R\$).

\begin{tabular}{lcc}
\hline & & Direct cost (R\$) \\
\cline { 2 - 3 } Components & Mean & ASE \\
\hline Animal nutrition & $18.292,00$ & 2.147 \\
Direct labor (MOD) & $2.072,00$ & 166 \\
Animals sold & $1.635,00$ & 495 \\
Electricity & 455,00 & 66 \\
Milking material & 327,00 & 38 \\
Animal health & 683,00 & 153 \\
Animal reproduction & 635,00 & 131 \\
Water & 312,00 & 117 \\
Fuel and lubricant & 471,00 & 95 \\
General maintenance & 212,00 & 34 \\
Total & $24.008,00$ & 2.750 \\
\hline
\end{tabular}

ASE $=$ Average standard error. Source: Authors.

For the monthly economic results (Table 3) obtained, it is verified that contribution margin (CM) obtained in this study was negative ( $\mathrm{R} \$-1,031.00$ ), demonstrating that there is no equilibrium point between activities analyzed, to cover the costs milk production (Sabbag and Costa 2015). This result is directly associated with the GSC generated, which was higher than the net income.

The net result was obtained by comparing revenues with costs and expenses, calculating the operation result in a given period, this economic result was also negative ( $\mathrm{R} \$-4,914.00)$, possibly due to the EBITDA, which was not adequate to cover the expenses. Through the income statement of the exercise (ISE) (Table 3) it is possible to obtain an organizational point of view, since in this study ISE model was adapted to include data related to CM and EBITDA, expecting to show how much net income, monetarily, left over from the operation to cover fixed expenses costs, enabling to know both cash expected balances and equivalents (Lopes et al., 2016). 
Table 3. Monthly Income Statement (MIS) from April 2018 to March 2019, calculated using the direct cost (DC) method, in 30 dairy farms on Semiarid region of Sergipe, Brazil.

\begin{tabular}{lcc}
\hline Description & Mean (R\$) & SD \\
\hline Monthly production in liters of milk & 18.27 & 2.666 \\
Average price/liter of milk (BRL) & 1,20 & 0,007 \\
Gross milk revenue (BRL) & 21.96 & 3.129 \\
Gross revenue from animals (BRL) & 1.63 & 425 \\
Total gross revenue (BRL) & 23.31 & 3.380 \\
(-) Taxes on sales (BRL) & 329,00 & 47 \\
(=) Net income (R\$) & 22.98 & 3.333 \\
(-) GSC (BRL) & $24.008,00$ & 2.750 \\
(=) Contribution margin (BRL) & $-1.031,00$ & 1.489 \\
(-) Labor costs (IL) (BRL) & $1.483,00$ & 140 \\
(-) Labor expenses (BRL) & $1.200,00$ & 0 \\
(-) General expenses (BRL) & 75,00 & 10 \\
(=)EBITDA (BRL) & $-3.295,00$ & 24.008 \\
(-) Depreciation (BRL) & $1.446,00$ & 187 \\
(-) Financial expenses (BRL) & 269,00 & 107 \\
(=) Net income result(BRL) & $-4.914,00$ & 1.558 \\
\hline
\end{tabular}

$\mathrm{SD}=$ Standard deviation; GSC = Goods sold cost; $\mathrm{IL}=$ Indirect labor; EBITDA = Profits before interest, taxes, depreciation and amortization, $\mathrm{BRL}=$ in Brazilian currency (R\$). Source: Authors.

Corroborating these results, the economic indicators based on net income (Table 4), showed that GSC was above it by 4.49 percentage points. The negative CM was possibly caused by the high production cost composing the GSC, that contributed to the net income by BRL - 0.20 (twenty cents) per liter of milk, characterizing the need for cost adjustments to be compatible with the revenue amount. Segala and Silva (2007), verified that milk production activity did not showed positive accounting result, mainly due the high production costs. Thus, due to the elevated GSC or low milk price, CM did not contribute positively to cover fixed costs and expenses, representing as the main cause of negative EBITDA, this indicates a problem with future cash flow (Malvessi \& Calil 2014).

The calculation of costs by DC based on the GSC developed for a given period of the production cycle allows to verify the conditions and to identify the necessary financial operations to bear fixed costs and expenses, or structural costs, in order to generate EBITDA and reimburse the invested capital. Variable costs, in this method called GSC, are accounted concomitantly with the respective revenue from milk and/or animals sales and the fixed costs, by their very nature are accounted for monthly according to their consumption at administration and production support processes. Therefore, DC method enables producers, under technical guidance, to identify the cost components that are not adequate, and correct them to obtain a positive MC, at least to the point of covering structural costs, including depreciation and financial expenses. 
Table 4. Economic indicators obtained by direct costing (CD) method, in Brazilian currency (BRL R\$).

\begin{tabular}{cc}
\hline Parameters & Mean (R\$) \\
\hline GSC /NI (\%) & 104,49 \\
Fixed cost and expenses /NI (\%) & 16,90 \\
Contribution margin/kg of milk & $-0,06$ \\
EBITDA/kg of milk (BRL) & $-3,295$ \\
GSC/kg of milk (BRL) & 1,31 \\
Fixed cost/kg of milk (BRL) & 0,21 \\
Total cost/kg of milk & 1,45 \\
NI/kg of milk & $-0,20$ \\
\hline
\end{tabular}

$\mathrm{NI}=$ Net income EBITDA $=$ Profits before interest, taxes, depreciation and amortization. Source: Authors.

\section{Conclusion}

Applying direct costing methodology in dairy farms generates relevant information about the business operation, with great applicability potential in milk husbandry. The economic result statements through MC and EBITDA represent the cash position at the end of the financial cycle allowing the producer to make decisions about production costs.

Apply accounting principles for costing the production of "in natura" milk using the direct costing methodology, inventorying variable costs and directly attributing fixed costs and expenses to the result, in addition to obtaining contribution margin and EBITDA, can be an indicator essential for quality management, with a strategic vision of the business.

Finally, new studies must be conducted in order to deepen specific questions that, perhaps, have remained to be clarified.

\section{Acknowledgments}

The authors are grateful to the Coordenação de Aperfeiçoamento de Pessoal de Nível Superior (CAPES) - Brazil, financial code 001 .

\section{References}

Brasil, Lei Federal n ${ }^{\circ}$ 11/71 de 25 de maio de 1971. Institui o programa de assistência ao trabalhador rural (FUNRURAL) e dá outras providências. Republica Federativa do Brasil.

Brasil, Lei Federal n ${ }^{\circ} 9.580$ de 22 de novembro de 2018. Regulamenta a tributação, a fiscalização, a arrecadação e a administração do Imposto sobre a Renda e Proventos de Qualquer Natureza. Republica Federativa do Brasil.

Costa, F., Cruz, A. P. C., Cherobim, A. P. M. S. \& Espejo, M. M. D. S. B. (2009). Determinants of Capital Structure of the Largest Companies in Southern Brazil in 2007. Revista de Contabilidade da UFBA, 3(2), 36-48.

EMDAGRO (2013). Empresa de Desenvolvimento Agropecuário de Sergipe, 2013. Boletim Agropecuário, março de 2013.

Junior, J. H. P. (eds) (1999). Gestão estratégica de custos. Atlas.

Lopes, M. A., Lima, A. L. R., Carvalho, F. D. M., Reis, R. P., Santos, Í. C. \& Saraiva, F. H. (2004). Controle gerencial e estudo da rentabilidade de sistemas de produção de leite na região de Lavras (MG). Ciência e Agrotecnologia, 28, 883-892.

Lopes, M. A., Reis, E. M. B., Demeu, F. A., Mesquita, A. A., Rocha, A. G. F. \& Benedicto, G. C. (2016). Uso de ferramentas de gestão na atividade leiteira: um estudo de caso no sul de Minas Gerais. Revista Científica de Produção Animal, 18(1), 26-44.

Ludke, M. \& Andre, M. E. D. A (4th ed) (2013). Pesquisas em educação: uma abordagem qualitativa. Bookman.

Marconi, M. A. \& Lakatos, E. M. (6th ed) (2009). Fundamentos da metodologia cientifica. Atlas, São Paulo.

Malvessi, O. \& Calil, J. F. (2014). Uma análise crítica da utilização do EBITDA (Earn Before Interest, Tax, Depreciation and Amortization) como ferramenta de avaliação do desempenho da empresa. Revista de Finanças e Contabilidade da UNIMEP, 1(1), 84-93.

Pelegrini, D. F., Lopes, M. A., Demeu, F. A., Rocha, Á. G. F., Bruhn, F. R. P. \& Casas, P. S. (2019). Effect of socioeconomic factors on the yields of familyoperated milk production systems. Semina: Ciências Agrárias, 40(3), 1199-1214. 
Research, Society and Development, v. 11, n. 2, e2911225328, 2022

(CC BY 4.0) | ISSN 2525-3409 | DOI: http://dx.doi.org/10.33448/rsd-v11i2.25328

Perez Jr., J. H. \& Oliveira, L. M., Costa, R. G. (8th ed) (2012). Gestão Estratégica de Custos. Editora Atlas S/A.

Rosseto, M., Batistella, V. M. C., \& Veiga, R. L. (2020). Análise de perigos e pontos críticos de controle: um estudo de caso em uma propriedade leiteira do Município de Sertão, Rio Grande do Sul, Brasil. Research, Society and Development, 9(8), e69985136-e69985136.

Sabbag, O. J. \& Costa, S. M. A. L. (2015). Análise de custos da produção de leite: aplicação do método de Monte Carlo. Extensão Rural, 22(1), 125-145.

Sabadin, M. \& Vizzotto, M. J. (2014). Calculation of const by costing method variable: case study in na enterprise service delivery. Revista Eletrônica de Ciências Sociais Aplicadas, 3(2), 44-69.

Santos, G. \& Lopes, M. A. (2014). Indicadores econômicos de sistemas de produção de leite em confinamento total com alto volume de produção diária. Ciência Animal Brasileira, 15(3), 239-248.

Segala, C. Z. S. \& Silva, I. D. (2007). Apuração dos custos na produção de leite em uma propriedade rural do município de Irani-SC. Custos e Agronegócio on line, 3(1), 61-83.

Silva, P. H. S., Chaves, A. R., Costa, L. B. F., Oliveira, A. G., Silva, L. H., Espindola, Y. M. \& Brumatti, R. C. (2020). Aplicabilidade de sistemas de simulação bio-econômica de propriedades rurais de bovinos de leite. Brazilian Journal of Development, 14(1), 1904-15.

Souza, A. A., Avelar, E. A. \& Boina, T. M. (2016). Activity-based costing: an analysis of the brazilian studies developed along the first decade of the century XXI. Revista de Informação Contábil, 10(2), 1-19.

Souza, L. O., Pedreiro, I. L. D., Barbosa, A. L. M. A., \& de Castro, W. A. (2019). A influência da Governança Corporativa na rentabilidade das Instituições Financeiras. Research, Society and Development, 8(8), e09881179-e09881179. 